\title{
A Hospital-based Prospective Study of Hypomagnesemia in Type 2 Diabetes Mellitus Patients
}

\author{
Purshottam L Gupta ${ }^{1}$, Brij Mohan Gupta², Ganpat Devpura ${ }^{3}$
}

\begin{abstract}
Background: Magnesium is the second most abundant intracellular cation in the body and recently there has been an emerging interest in its major role played in various physiological and disease states of the body. Its deficiency is being correlated with pathogenesis, glycemic control, and various complications occurring in patients of diabetes mellitus (DM) in many studies.

Aim and objective: To estimate serum magnesium levels in diabetic patients and correlating it with pathogenesis, duration of diabetes, poor glycemic control, and various complications in our tertiary care hospital patients.

Materials and methods: This is a case-control, prospective study comprising 120 diabetic patients diagnosed as per recommended criteria of ADA and were evaluated at NIMS Medical College, Jaipur, Rajasthan. Keeping serum magnesium value threshold of $1.6 \mathrm{mg} / \mathrm{dL}$, all patients were divided into two groups; hypomagnesemic(s) and normomagnesemic(s). Twenty-five healthy age-matched controls were also enrolled and compared.

Results: We observed 120 patients (52.5\% males and $47.5 \%$ females), with age ranges between 36 years and 78 years; however, $60 \%$ of patients were in the range of 40-65 years. Mean serum values in hypomagnesemic, normomagnesemic, and healthy controls were detected in the range $1.54 \pm 0.43,1.81 \pm 0.56$, and $2.12 \pm 0.67$, respectively. $60.8 \%$ of diabetic patients had one or more diabetic complications; more in hypomagnesemic (83.3\%) compared with normomagnesemic (51.9\%). Microvascular complications were the most common. A single case of neuromuscular weakness was also detected.

Conclusion: Hypomagnesemia is common in patients of type 2 DM (T2DM) and has a negative correlation with its incidence, duration of disease, poor glycemic control, and various complications of DM. The therapeutic potential of serum magnesium is worth exploring via large clinical trials. Since replenishment of serum magnesium is a simple clinical entity, thus, it will be prudent to measure serum magnesium in each diabetic patient and replenish it accordingly.

Keywords: Diabetes complications, Diabetes mellitus, Hypomagnesemia, Neuromuscular weakness, Poor control. Journal of Mahatma Gandhi University of Medical Sciences \& Technology (2021): 10.5005/jp-journals-10057-0148
\end{abstract}

\section{INTRODUCTION}

Magnesium is the second most abundant intracellular cation in the body and acts as a cofactor in various enzymatic reactions of body cells. Recently, there has been an emerging interest in its major role played in various physiological activities and disease states. Chronic low magnesium states have been associated with several chronic diseases including DM, HT, CAD, asthma, and osteoporosis. Various clinical trials have found that magnesium levels are lower in diabetics compared with non-diabetic controls. ${ }^{1-4}$ The relationship of hypomagnesemia with the pathogenesis of diabetes, poor glycemic control, and with various long-term complications of diabetes mellitus (DM) also have been reported. ${ }^{1}$ Present study was carried out to estimate the levels of serum magnesium in DM patients and correlate these levels with the pathogenesis, duration of disease, poor glycemic control, and also with various complications in our hospital tertiary care hospital group of patients.

\section{Materials and Methods}

The study was conducted at NIMS Medical College and Hospital, Jaipur between June 2019 and December 2019. Patients with type 2 DM (T2DM), diagnosed as per recommended criteria of ADA, with age above 35 years were included in the study. Patients on drugs and with diseases likely to affect the magnesium levels were excluded (Table 1). Twenty-five healthy controls of similar age distribution were also enrolled and compared. Written informed consent was taken from the patients and controls. ${ }^{1,3}$ Department of General Medicine, National Institute of Medical
Sciences and Research, Jaipur, Rajasthan, India
${ }^{2}$ Department of Forensic Medicine, Mahatma Gandhi Medical College
and Hospital, Jaipur, Rajasthan, India

Corresponding Author: Purshottam L Gupta, Department of General Medicine, National Institute of Medical Sciences and Research, Jaipur, Rajasthan, India, Phone: +91 9414447233, e-mail: drguptapl@gmail.com How to cite this article: Gupta PL, Gupta BM, Devpura G. A Hospitalbased Prospective Study of Hypomagnesemia in Type 2 Diabetes Mellitus Patients. J Mahatma Gandhi Univ Med Sci Tech 2021;6(2): 56-59.

Source of support: Nil

Conflict of interest: None

Detailed history taking and clinical examination including fundus oculi were done in all the patients to diagnose and detect the presence of any microvascular and macrovascular complications of DM. Peripheral neuropathy assessment was done clinically and quantified by neuropathy disability score. Retinopathy was evaluated by direct ophthalmoscopy and nephropathy by serum creatinine and urine microalbuminuria estimation. All patients underwent investigation for serum $\mathrm{Mg}$, FBG, PPBG, HbA1c, lipids, urea, creatinine, and other relevant ones (Table 2). Urine was tested for micro- and macroalbuminuria. The normal serum level in our laboratory is $1.6-2.6 \mathrm{mg} / \mathrm{dL}$. Patients 
A Hospital-based Prospective Study of Hypomagnesemia in Type 2 Diabetes Mellitus Patients

Table 1: Drugs and diseases known to affect Mg levels and were excluded from the study

\begin{tabular}{|c|c|}
\hline Drugs & Diseases \\
\hline - Diuretics & - Type 1 DM patients \\
\hline $\begin{array}{l}\text { - Magnesium-containing } \\
\text { antacids }\end{array}$ & $\begin{array}{l}\text { Critically ill patients (CVA, acute } \\
\text { MI, acute hepatic and renal } \\
\text { failure, and sepsis) }\end{array}$ \\
\hline $\begin{array}{l}\text { - Multivitamins, minerals } \\
\text { (tablet/syrup/injections) }\end{array}$ & $\begin{array}{l}\text { - Recent metabolic acidosis/lactic } \\
\text { acidosis }\end{array}$ \\
\hline - Chronic alcoholism & - Hematological malignancies \\
\hline - Digoxin & $\begin{array}{l}\text { - Pregnant/lactating women with } \\
\text { DM }\end{array}$ \\
\hline - Aminoglycosides & $\begin{array}{l}\text { - Patients with parathyroid, thyroid } \\
\text { and adrenal dysfunction, CKD }\end{array}$ \\
\hline - Amphotericin B & $\begin{array}{l}\text { - Malabsorption or chronic } \\
\text { diarrhea }\end{array}$ \\
\hline
\end{tabular}

Table 2: Comparison of patients and controls

\begin{tabular}{llll}
\hline & $\begin{array}{l}\text { Patients } \\
(N=120)\end{array}$ & $\begin{array}{l}\text { Controls } \\
(N=25)\end{array}$ & p value \\
\hline Age (years) & $55.9 \pm 8.0$ & $55 \pm 6.4$ & 0.507 \\
Male $(\%)$ & $52.50 \%$ & $56 \%$ & 0.75 \\
BMI $\left(\mathrm{kg} / \mathrm{m}^{2}\right)$ & $27.9 \pm 6.2$ & $25.6 \pm 6.4$ & 0.102 \\
SBP $(\mathrm{mm} \mathrm{Hg})$ & $138.3 \pm 21.7$ & $135 \pm 15$ & 0.36 \\
DBP $(\mathrm{mm} \mathrm{Hg})$ & $89.2 \pm 14.9$ & $82.1 \pm 7.7$ & 0.0007 \\
FBG $(\mathrm{mg} / \mathrm{dL})$ & $168.7 \pm 24.1$ & $109.3 \pm 29.3$ & 0.0 \\
PPBG $(\mathrm{mg} / \mathrm{dL})$ & $258.9 \pm 23.2$ & $243.0 \pm 24.6$ & 0.003 \\
HbA1c & $8.2 \pm 0.56$ & $6.3 \pm 0.4$ & 0.0 \\
Serum magnesium $(\mathrm{mg} / \mathrm{dL})$ & $1.73 \pm 0.49$ & $2.12 \pm 0.67$ & 0.006 \\
Serum calcium $(\mathrm{mg} / \mathrm{dL})$ & $9.8 \pm 0.65$ & $9.95 \pm 0.7$ & 0.325 \\
Serum creatinine $(\mathrm{mg} / \mathrm{dL})$ & $0.95 \pm 0.57$ & $0.84 \pm 0.23$ & 0.115 \\
Total cholesterol $(\mathrm{mg} / \mathrm{dL})$ & $190.4 \pm 46.9$ & $176 \pm 34.5$ & 0.078 \\
TG $(\mathrm{mg} / \mathrm{dL})$ & $143.6 \pm 40.03$ & $140 \pm 32.4$ & 0.629 \\
\hline
\end{tabular}

$\mathrm{BMI}$, body mass index; SBP, systolic blood pressure; DBP, diastolic blood pressure; FBG, fasting blood sugar; PPBG, postprandial blood glucose; TG, triglyceride

with a threshold magnesium value $<1.6 \mathrm{mg} / \mathrm{dL}$ were considered hypomagnesemic.

Serum magnesium was assessed by the photometric method (Vitros, Ortho Clinical Diagnostics, Python 3 programming language with Scipy analytical package was used for the analysis of data.). All parametric variables were expressed as mean \pm SD. The comparison between groups was made by unpaired $t$-test and $p$ values $<0.05$ were considered significant.

\section{Results and Observations}

\section{Study of Serum Magnesium Levels in DM Patients}

One hundred and twenty (52.5\% males and $47.5 \%$ females) diabetic patients (hereafter referred to as patients), aged between 36 and 78 with the majority (60\%) in-between 40-65; diagnosed with ADA recommended criteria were studied. The mean BMI of patients was $27.9 \pm 6.2$. Age-matched 25 healthy controls (hereafter referred to as controls) were also enrolled in the study. A detailed comparison is depicted in Table 2.
Table 3: Characteristics of hypomagnesemic vs normomagnesemic

\begin{tabular}{|c|c|c|c|}
\hline & $\begin{array}{l}\text { Hypomagne- } \\
\text { semic }(N=36)\end{array}$ & $\begin{array}{l}\text { Normomagne- } \\
\text { semic }(N=84)\end{array}$ & $p$ value \\
\hline Age (years) & $57.6 \pm 8.4$ & $55.3 \pm 7.6$ & 0.16 \\
\hline Male (\%) & $52.70 \%$ & $52.30 \%$ & 0.968 \\
\hline BMI $\left(\mathrm{kg} / \mathrm{m}^{2}\right)$ & $28.06 \pm 6.7$ & $27.84 \pm 5.8$ & 0.86 \\
\hline Duration of DM (years) & $6.27 \pm 3.4$ & $6.82 \pm 2.6$ & 0.38 \\
\hline $\mathrm{SBP}(\mathrm{mm} \mathrm{Hg})$ & $142.86 \pm 20.5$ & $136.43 \pm 22.84$ & 0.131 \\
\hline $\mathrm{DBP}(\mathrm{mm} \mathrm{Hg})$ & $92 \pm 11.6$ & $88 \pm 17.6$ & 0.145 \\
\hline $\mathrm{FBG}(\mathrm{mg} / \mathrm{dL})$ & $175 \pm 25.3$ & $165 \pm 22.8$ & 0.05 \\
\hline PPBG (mg/dL) & $268 \pm 27.4$ & $255 \pm 18.2$ & 0.01 \\
\hline $\mathrm{HbA1c}$ & $8.92 \pm 0.43$ & $7.98 \pm 0.67$ & 0 \\
\hline $\begin{array}{l}\text { Serum magnesium } \\
(\mathrm{mg} / \mathrm{dL})\end{array}$ & $1.54 \pm 0.43$ & $1.81 \pm 0.56$ & 0.004 \\
\hline $\begin{array}{l}\text { Serum calcium (mg/ } \\
\mathrm{dL} \text { ) }\end{array}$ & $9.86 \pm 0.70$ & $9.90 \pm 0.6$ & 0.765 \\
\hline $\begin{array}{l}\text { Serum creatinine (mg/ } \\
\mathrm{dL} \text { ) }\end{array}$ & $1.03 \pm 0.57$ & $0.92 \pm 0.57$ & 0.334 \\
\hline $\begin{array}{l}\text { Total cholesterol (mg/ } \\
\mathrm{dL} \text { ) }\end{array}$ & $196 \pm 48.5$ & $188 \pm 45.38$ & 0.4 \\
\hline TG $(\mathrm{mg} / \mathrm{dL})$ & $152 \pm 40.32$ & $140 \pm 39.74$ & 0.136 \\
\hline $\begin{array}{l}\text { Microalbuminuria } \\
\text { (mg/day) }\end{array}$ & $210.18 \pm 80$ & $183.1 \pm 60$ & 0.07 \\
\hline
\end{tabular}

The patients and controls were comparable based on age and gender distribution. However, there was a significant difference in serum magnesium, BMI, SBP, DBP, and $\mathrm{HbA} 1$ c levels between them.

\section{Correlation of Serum Magnesium to Diabetic Complications}

Furthermore, the patients were divided into two groups according to the threshold level of serum magnesium $(1.6 \mathrm{mg} /$ $\mathrm{dL}$ ), i.e., hypomagnesemic and normomagnesemic. Mean serum magnesium levels in two diabetic groups are depicted in Table 3.

The two groups were statistically similar based on age, gender, duration of DM, and BMI levels. The hypomagnesemic have significantly higher $\mathrm{HbA1c}$ levels than normomagnesemic suggesting poorer glycemic control in the former. All other parameters were comparable.

Furthermore, both diabetic groups were compared for various complications.

Total 73 patients in both the diabetic groups had one or more than one complication. Of this, 53 patients had a single complication. Nine patients had two complications. Six patients had three complications and five had four complications. Fortytwo (57.5\%) patients had neuropathy, 15 (20.5\%) had nephropathy, and 17 (23.2\%) had retinopathy. One patient had a neuromuscular weakness.

\section{Correlation of Serum Magnesium to Duration of Diabetes}

The patients were divided into three groups based on their diabetes duration. Sixty-five (54.1\%) patients had a history of $<6$ years, 20 (16.6\%) patients between 6 years and 12 years, and 29.1\% over 12 years. 
A Hospital-based Prospective Study of Hypomagnesemia in Type 2 Diabetes Mellitus Patients

Table 4: Diabetic complications in hypomagnesemic vs normomagnesemic

\begin{tabular}{lllll}
\hline Complications & $\begin{array}{l}\text { Hypomagnesemic } \\
(N=36)\end{array}$ & $\begin{array}{l}\text { Normomagnesemic } \\
(N=84)\end{array}$ & Total & $p$ value \\
\hline $\begin{array}{l}\text { Microvascular } \\
\text { Peripheral neuropathy }\end{array}$ & $18(50.0 \%)$ & $24(28.6 \%)$ & 42 & 0.024 \\
$\quad \begin{array}{l}\text { Nephropathy } \\
\text { Retinopathy }\end{array}$ & $7(19.4 \%)$ & $8(9.5 \%)$ & 15 & 0.132 \\
$\begin{array}{l}\text { Macrovascular } \\
\text { CAD }\end{array}$ & $9(25.0 \%)$ & $8(9.5 \%)$ & 17 & 0.026 \\
CVA & $10(27.7 \%)$ & $10(11.9 \%)$ & 20 & 0.033 \\
PVD & $4(11.1 \%)$ & $6(7.1 \%)$ & 10 & 0.471 \\
Others & $2(5.5 \%)$ & $4(4.7 \%)$ & 6 & 0.855 \\
$\quad \begin{array}{l}\text { Neuromuscular weakness } \\
\text { (Quadriparesis) }\end{array}$ & $1(2.7 \%)$ & 0 & & \\
\hline
\end{tabular}

Table 5: Hypomagnesemia vs diabetic complications

\begin{tabular}{llll}
\hline Patients $(N=120)$ & $\begin{array}{l}\text { Hypomagne- } \\
\text { semic }(N=36)\end{array}$ & $\begin{array}{l}\text { Normomagne- } \\
\text { semic }(N=84)\end{array}$ & Total \\
\hline With complications & $30(83.3 \%)$ & $43(51.9 \%)$ & 73 \\
Without complications & $6(16.7 \%)$ & $41(48.8 \%)$ & 47 \\
\hline
\end{tabular}

Thus, 73 (60.83\%) diabetics had one or more complications. This was significantly more in hypomagnesemic(s) (83.3\%) compared with normomagnesemic(s) (51.9\%)

Patients with a longer duration of diabetes had higher mean $\mathrm{HbA1c}$ values and lower mean serum magnesium values. Inverse correlation between duration of diabetes and serum magnesium levels is well evident (Tables 4 and 5).

\section{Discussion}

Type $2 \mathrm{DM}$ is a chronic metabolic disorder, progressive in nature with high prevalence. Magnesium (Mg) is one of the most common minerals and second most abundant intracellular cation in the body. It is a cofactor in various enzymatic reactions of body cells and, thus, plays a major role in various cell processes. Recently, there has been an emerging interest in its deficiency and correlation with DM. Many trials have shown that mean plasma magnesium levels are lower in diabetics compared with non-diabetics. ${ }^{1,2,5-9}$

Causes of hypomagnesemia are multifactorial which includes either poor magnesium-rich dietary intake or loss of magnesium in urine by rampant use of diuretics or reduced tubular reabsorption ${ }^{4}$ due to insulin resistance ${ }^{10-12}$ or development of diabetic autonomic neuropathy. In our present study, out of 120 patients, 36 (30\%) patients had hypomagnesemia. A similar incidence has been (13.5-47\%) has been observed in other studies. ${ }^{1}$

A recent meta-analysis of 13 selected studies, 9 showed a statistically significant inverse association between magnesium intake and risk of diabetes and concluded that low magnesium intake is significantly associated with the risk of T2DM in a doseresponse manner. ${ }^{1}$

Eighty-eight patients had $\mathrm{HbA1c}>7$, indicating poor glycemic control (Fig. 1). An inverse correlation between serum magnesium and $\mathrm{HbA} 1 \mathrm{C}$ is observed. Ramadass et al. ${ }^{9}$ also observed declined $\mathrm{mg}$ levels with a rise in $\mathrm{HbA1c}$ and duration of diabetes.

We have observed that patients with a longer duration of DM had higher mean $\mathrm{HbA1c}$ values and lower mean serum magnesium values (Table 6). However, few others have ${ }^{8,13}$ concluded that serum

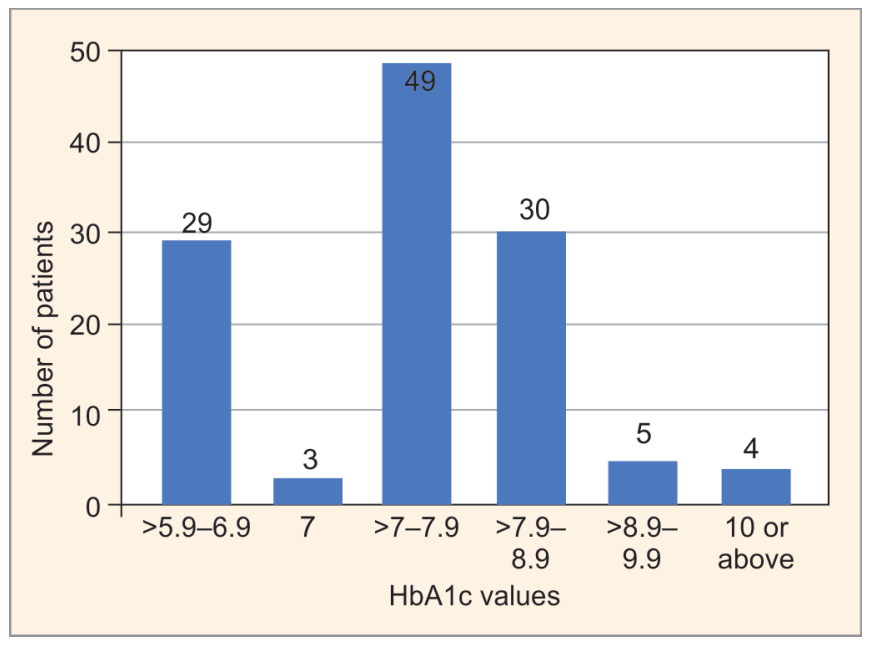

Fig. 1: Distribution of $\mathrm{HbA} 1 \mathrm{c}$ levels in patients

Table 6: Serum magnesium level vs duration of diabetes

\begin{tabular}{llll}
\hline $\begin{array}{l}\text { Duration of } \\
\text { diabetes (years) }\end{array}$ & No. of patients & Mean HbA1c & $\begin{array}{l}\text { Mean serum } \\
\text { magnesium } \\
(\mathrm{mg} / \mathrm{dL})\end{array}$ \\
\hline$<6$ & 65 & $7.9 \pm 0.45$ & $1.85 \pm 0.52$ \\
$>6-12$ & 20 & $8.2 \pm 0.6$ & $1.65 \pm 0.39$ \\
$>12$ & 35 & $8.6 \pm 0.62$ & $1.55 \pm 0.49$ \\
\hline
\end{tabular}

magnesium has no direct relationship with diabetic duration if the diabetes is well controlled. . $^{8,13}$

Hypomagnesemia has been related to elevated blood pressure, dyslipidemia, increased inflammatory burden, oxidative stress, carotid wall thickness, and coronary heart disease. ${ }^{14-17}$ Hypomagnesemia is known to be accompanied by thrombotic tendencies, increased platelet aggregability, increased coronary artery responsiveness to contractile stimuli. CAD incidence was observed at $27.7 \%$ in hypomagnesemic and $11.9 \%$ in normomagnesemic. This difference was found to be statistically significant.

Peripheral neuropathy was also significantly different in both groups ( 50.0 vs $28.6 \%$ ). Other studies have also found a relationship between low magnesium levels with diabetic peripheral neuropathy. ${ }^{2} \mathrm{An}$ improvement in the nerve conduction 
velocity following magnesium supplementation is being studied. ${ }^{18}$ Nephropathy was also found prevalent in hypomagnesemic (19.4 vs 9.5\%). Corsonello et al. ${ }^{19}$ had similar observations.

We also observed a higher incidence of retinopathy (25 vs $9.5 \%)$ among hypomagnesemic. This relationship between hypomagnesemia and retinopathy was earlier established by Fujii et al. ${ }^{20}$ A study from Brazil with type 1 and type 2 diabetics, however, did not demonstrate a significant correlation between the severity of retinopathy and magnesium concentration in the plasma. ${ }^{4}$

One patient presented with severe neuromuscular weakness (Quadriparesis) ${ }^{21}$ and had severe hypomagnesemia (1.12 mg/dL); was refractory to hypokalemia and hypocalcemia correction which improved completely both clinically and biochemically only after magnesium correction. Dasgupta et al. ${ }^{21}$ had similar observations. Hypomagnesemia causes both hypokalemia and hypocalcemia via the action on kidneys and parathyroid gland, respectively, via the action on renal outer medullary potassium (ROMK), ${ }^{22}$ the inwardly rectifying $\mathrm{K}$ channel in the distal nephron, required for the backleak of $\mathrm{K}^{+}$. A low intracellular $\mathrm{Mg}^{2+}$ increases ROMK efflux activity and thereby $\mathrm{K}^{+}$wasting. ${ }^{22}$ Hypomagnesemia causes hypocalcemia causing inappropriately low parathyroid secretion and hormone resistance ${ }^{23}$ and also decreased action of 1,25 hydroxylase.

\section{ConcLusion}

Hypomagnesemia is common in patients of T2DM and has a negative correlation with its incidence, duration of disease, poor glycemic control, and various microvascular and macrovascular complications of DM. The therapeutic potential ${ }^{2,24,19}$ of serum magnesium is worth exploring via large clinical trials. ${ }^{25}$ Since replenishment of serum magnesium is a simple clinical entity, thus, it will be prudent to measure serum magnesium in each diabetic patient.

\section{ACKnowledgments}

The authors would like to thank the NIMS hospital laboratory, medicine ward, nursing staff, and participating patients and controls for their cooperation in the study. A sincere thanks to Er. Kartikeya Gupta (kartikeya.gupta4@gmail.com) for helping with statistical analysis during the study.

\section{References}

1. Pham PC, Pham PM, Pham SV, et al. Hypomagnesaemia in patients with type 2 diabetes. Clin J Am Soc Nephrol 2007;2(2):366-372. DOI: 10.2215/CJN.02960906.

2. de Lordes Lima M, Cruz T, Pousada JC, et al. The effect of magnesium supplementation in increasing doses on the control of Type 2 DM. Diabetes Care 1998;21(5):682-686. DOI: 10.2337/diacare.21.5.682.

3. Wälti MK, Zimmermann MB, Walczyk T, et al. Measurement of magnesium absorption and retention in type 2 DM with use of stable isotopes. Am J Clin Nutr 2003;78(3):448-453. DOI: 10.1093/ ajcn/78.3.448.

4. Correa ZM, Freitas AM, Marcon IM. Risk factors related to the severity of diabetic retinopathy. Arq Bras Oftalmil 2003;66(6):739-743. DOI: 10.1590/S0004-27492003000700002.

5. Harrison's principles of internal medicine. 18th ed., McGraw Hill; 2011. pp. 2968-3002.
6. Raheja BS, Kapur A, Bhoraskar A, et al. Diabetes care Asia - India study: Diabetes care in India current status. J Assoc Physicians India 2001;49:717-722.

7. Kulkarni AG, Shendge SK, Shinde V. Study of serum magnesium level in type 2 diabetes mellitus. IOSR Journal of Dental and Medical Sciences (IOSR-JDMS) 2014;13(4 Ver. VII):115-119. DOI: 10.9790/08531347115119.

8. Kauser MM, Afreen A, Prabhakar K, et al. Study of serum magnesium in type 2 diabetes mellitus and its correlation with the modality of treatment - A South Indian study. Int J Biomed Adv Res 2014;5(8):361363. DOI: 10.7439/ijbarSSN: 2229-3809 (Online) Journal.

9. Ramadass S, Basu S, Srinivasan AR. SERUM magnesium levels as an indicator of status of diabetes mellitus type 2. Diabetes Metab Syndr 2015;9(1):42-45. DOI: 10.1016/j.dsx.2014.04.024.

10. Barbagallo M, Dominguez LJ. Magnesium metabolism in type 2 diabetes mellitus, metabolic syndrome and insulin resistance. Arch Biochem Biophys 2007;4558(1):40-47. DOI: 10.1016/j.abb.2006.05.007.

11. Takaya J, Higashino $H$, Kobayashi Y. Intracellular magnesium and insulin resistance. Magnes Res 2004;17(2):126-136.

12. Djurhuus MS. New data of mechanisms of hypomagnesemia in type 1 diabetes mellitus. Magnes Res 2001;14(3):217-223.

13. Rude RK. Magnesium deficiency and diabetes mellitus causes and effects. Postgrad Med J 1992;92(5):217-224. DOI: 10.1080/00325481.1992.11701494.

14. Rayssignier Y. Role of magnesium and potassium in the pathogenesis of arteriosclerosis. Magnesium 1984;3:226-238.

15. Ma J, Folsom AR, Melnick SL, et al. Association of serum and dietary magnesium with cardiovascular disease, hypertension, diabetes, insulin, and carotid arterial wall thickness: The ARIC study. Atherosclerosis risk in communities study. J Clin Epidemio 1995;48(7):927-940. DOI: 10.1016/0895-4356(94)00200-A.

16. Guerrero-Romero F, Rodriguez-Moran M. Hypomagnesaemia, oxidative stress, inflammation, and metabolic syndrome. Diabetes Metab Res Rev 2006;22(6):471-476. DOI: 10.1002/dmrr.644.

17. Mohan V, Shanthirini CS, Deepa M. Chennai urban population study-16. Diabesis Res Clin pract 1998;34(1):29-36. DOI: 10.1016/ S0168-8227(96)01327-7.

18. De Leeuw I, Engelen W, De Block C, et al. Long term magnesium supplementation influences favourably the natural evolution of neuropathy in Mg-depleted type 1 diabetic patients (T1dm). Magnes Res 2004;17(2):109-114.

19. Corsonello A, lentile $R$, Buemi $M$, et al. Serum ionized magnesium levels in type 2 diabetic patients with microalbuminuria or clinical proteinuria. Am J Nephrol 2000(3):187-192. DOI: 10.1159/000013582.

20. Fujii S, Takemura T, Wada M, et al. Magnesium levels in plasma erythrocytes and urine in patients with diabetes mellitus. Horm Metab Res 1982;14(3):61-62. DOI: 10.1055/s-2007-1018954.

21. Dasgupta A, Saikia UK, Sharma D, et al. Quadriparesis in diabetes due to dyselectrolytemia. Indian J Endocrinol Metal 2010;14(1):27-29.

22. Huang $\mathrm{CL}$, Kuo E. Mechanism of hypokalemia in magnesium deficiency. J Am Soc Nephrol 2007;18(10):2649-2652. DOI: 10.1681/ ASN.2007070792.

23. Suh S, Tashjian A, Matsuo N, et al. Pathogenesis of hypocalcemia in primary hypomagnesaemia: normal end-organ responsiveness to parathyroid hormone, impaired parathyroid gland function. J Clin Invest 1973;52(1):153-160. DOI: 10.1172/JCI107159.

24. Paolisso G, Sgambato S, Pizza G, et al. Improved insulin response and action by chronic magnesium administration in aged NIIDM subjects. Diabetes Care 1989;12(4):265-269. DOI: 10.2337/diacare.12. 4.265.

25. Volpe SL. Magnesium in disease prevention and overall health. Adv Nutr 2013;4(3):378S-383SS. DOI: 10.3945/an.112.003483. 